\title{
On Some Recently Discovered Translations from Edgar Allan Poe's Work - by Ștefan Petică - at the End of the 19th Century
}

\author{
Nicoleta Călina, Ph.D. \\ University of Craiova, Romania
}

Doi: 10.19044/esj.2018.c3p10 ～URL:http://dx.doi.org/10.19044/esj.2018.c3p10

\begin{abstract}
The first authentic Romanian Symbolist writer - poet, novelist, playwright, journalist, sociologist, Ștefan Petică (1877-1904) - was also a skilled translator, as most of the Romanian writers at the end of the Nineteenth century used to be. For more than 120 years, there was no information on the translator of two volumes rendered into Romanian from Edgar Allan Poe's work and published in 1896 and, respectively, in 1897, at "Samitca" Publishing House in Craiova.
\end{abstract}

Keywords: Ștefan Petică, translations, Edgar Allan Poe, Samitca Publishing House

\section{Introduction}

Our paper brings to light some recent considerations around the personality of the first authentic Romanian symbolist writer, Ștefan Petică, and is the result of the research of many years on the multiple aspects of his life and activity. Born on the 20th January 1877 (Bucești, Galaţi), Ştefan Petică, poet, novelist, playwright, journalist, sociologist, was also a talented translator, as most of the Romanian writers at the end of the Nineteenth century used to be.

I.

Even during the last year of his high school (between 1892-1896 he attended the courses of the "Nicolae Bălcescu" High School from Brăila) his interest in translation, and not only in writing, is extremely relevant.

In 1896 he had already had his literary debut in one of the most prestigious publications from Bucharest - where the Romanian literary elite of the time was publishing, "Lumea Nouă literară şi ştiinţifică" - whose constant collaborator he became. 
As editor of the Omnia edition of this author, published at the prestigious National Museum of the Romanian Literature Publishing House, I have tried to identify all the writings and translations of Ştefan Petică that were not published in previous editions - that of Nicolae Davidescu and Eufrosina Molcuţ. The starting point of this research was the Library of the Romanian Academy, the place where most of the manuscripts are being preserved, together with books and articles in the publications of the time: "Literatorul", "Literatură şi artă română", "Noua revistă română", "Lumea Nouă", "România Jună", "România Ilustrată", "Dorobanţul", "Depeşa", "Economia Naţională" - and even his original translations from Edgar Allan Poe, that were published in 1896, entitled Nuvele extraordinare (Extraordinary Short Stories), at Institutul de Editură "Ralian şi Ignat Samitca" Publishing House from Craiova, within the Collection Biblioteca de Popularizare - Literatură, Ştiinţă, Artă, no. 19 (Library of Popularization - the Collection of Literature, Science, Art) and Scrisoarea furată (The Purloined Letter), in 1897, at the same Publishing House, in the same Collection, nr. $30^{18}$.

Samitca Publishing House was one of the oldest and greatest publishing houses in Craiova; it started its activity in 1835 and it was for almost a century the beacon for the intellectuals of Craiova. It was like a workshop for those who loved literature and knowledge; Samitca family was enthusiastic, either if we take into consideration the father (Iosif), or the two sons (Ignat and Ralian) that continued his work, always in a close contact with the intellectuals of the city; as publishers, they were eager to participate in the idealistic fervor of their customers, and of the cultural life of Craiova.

Deep thoughts for a long time were manifested to this extent only through small actions such as the "Little Library of Interesting Histories" / "Mica bibliotecă a istorioarelor interesante" started in 1885, then crystallized in a concept and in a well-defined work plan - such as the Library of Popularization - the Collection of Literature, Science, Art (Biblioteca de Popularizare - Literatură, Ştiinţă, Artă) and the Collection of Famous Novels (Colecția Romanelor Celebre) - founded in 1895, two epochal initiatives, which have greatly contributed to the development of the reading taste, facilitating through translations the contact with the young generation, with the universal literature and its great writers. ${ }^{19}$ The collection entitled by the

\footnotetext{
${ }^{18}$ Edgar Allan Poe, Nuvele extraordinare (Extraordinary Short Stories), translation by St. P., Ralian and Ignat Samitca Publishing Institute, Library of Pouplarization - the Collection of Literature, Science, Art, no. 19 Craiova, 1896, p. 114;

Edgar Allan Poe, translation by de St. P., The Purloined Letter and other extraordinary stories Library of Pouplarization - the Collection of Literature, Science, Art, no. 30 Craiova, 1897, p110.

${ }^{19}$ Dumitru Tomescu, Contribuţiuni la istoricul tipografiei oltene „Samitca” (Contributions to the history of Samitca pulbishing house), 1835-1922, Scrisul Românesc Publishing House, Craiova, s.a., p. 41.
} 
publisher The Library for Popularization, created during the Belle Époque period, contains some of the most in vogue names of European and American writers; its owner and editors meant to be, through the translations published within, the guiding light for artistic education of the people of Craiova. It is the place where great literary works were published and used either as auxiliary material for students, or as guide for the cultural life in the city and always in competition with those existing in Bucharest.

Important works - from the universal literature will have been translated and published here - belonging to: Vladimir Korolenko, Björnson, Lev Tolstoy, Balzac, Guy de Maupassant, Pushkin, Brandes, Heine, Ibsen, Francois Coppée, Alexandre Dumas, Wolfgang V. Goethe, Edgar Allan Poe, Hans Schmidt, Sully Prudhomme, Bret Harte, Dostoevsky, Shakespeare, Molière, Bourget, Benjamin Constant, Emile Zola, Alphonse Daudet, Georges Sand, Charles Dickens, Daniel de Foe, Oliver Swift, but also Dante Alighieri, Cervantes and Homer.

To conceive and realize in a provincial town, almost 150 years ago in a state that had had recently gained its independence - such a distinguished and audacious editorial plan with aims so high and so less commercial, at the moment when not even the Capital, Bucharest, did not manage to raise above small initiative, is a huge responsibility and an admirable proof of great courage, that is worth to be admired as of illustrious precursors.

The work of the Samitca family at their Publishing and Printing House was so remarkable, that in 1900 the institution received two silver medals at the Universal Exposition in Paris for the quality, elegance, graphic art and cultural value of the volumes. ${ }^{20}$

Petică translated the two volumes from Edgar Allan Poe's stories within the first year since the launch of this valuable collection. As his closest friends and collaborators stated, he thoroughly studied French, German and English, already knew Russian and Italian; in addition, he obtained almost all the catalogues of the bookshops in the country and abroad (some of them are still preserved at the Museum of History Galați, Ivești subsidiary), from which it was supplied; the titles of the books ordered abroad show a huge thirst for knowledge, covering a wide range of interests, from literature to philosophy, from mathematics to psychology, from criticism to art history, from sociology to history, making him aware of everything in connection with contemporary culture: "[...] He made me the impression of a man who was not only aware of the entire literary movement of the time, but who had tried to find the solving of the aesthetic problems that had been discussed at that time, and to

${ }^{20}$ Dumitru Tomescu, op. cit., p. 41. 
make new ways to accomplish the beauty. He had an overly rich vocabulary and expressed himself with amazing ease and grace. “21

Ștefan Petică's first biographer, a close friend, Grigore Tăbăcaru, mentions: "he had a vast culture and he was perhaps the one of the most cultivated man of letters of the time ${ }^{22 ،}$. The cultural opening demonstrated by Petică still impresses: the German, English, Italian and French poetry and the Pre-Raphaelism promoters had been studied with a depth that very few of his contemporaries would have been able to do. Petică absorbed the culture with avidity, and even though in 1898 he enrolled - but without obtaining the degree - at the Faculty of Letters and Philosophy and later on at the Faculty of Mathematics in Bucharest, he could not have become an ordinary student, because his job as a journalist would not have allowed him to pass all his examinations in time; besides, he was simultaneously interested in philosophy, aesthetics, mathematics, foreign languages and politics, trying to encompass as much as possible from each. The time for the study at the University remained precarious. ${ }^{23}$

It is very interesting how, for more than 120 years, there was no information on the translator of these two Poe's volumes. We initiated our research form a postcard that belonged to the Ștefan Petică, exposed to the History Museum Galați, Ivești subsidiary), dated 22 April 1896, sent by Ralian and Ignat Samitca, the two editors from Craiova (the signature belongs to them - see Image nr. 1, and the postcards has the printed header of the Publishing House - see Image nr. 2) to Ștefan Petică at his address in Brăila, while he was in the last year of study in high school. This is the text of it:

"April 22nd 1896

To Mr. Șt. Petică

Bulev. Cuza, 69, Brăila

We have received your postcard form 18/30, as well as your manuscript, that we have already sent to Mr. Hussar in Munich, in order to express his opinion on it. As soon as we will get His answer, we will let you know.

Respectfully yours,

R. and I. Samitca" 24

${ }^{21}$ George Tutoveanu: Ştefan Petică, in "Freamătul“, Bârlad, II, no. 1-3, 1912, p. 5

22 Grigore Tăbăcaru apud Gabriel Drăgan, Un prinț al poeziei (A Prince of Poetry), in "Univers literar" (Literary Universe), year XLV, no. 33, 1929

${ }^{23}$ Mihai Zamfir, Ştefan Petică, unicul (Stefan Petica, the only one), in Intoarcerea la cărți (Return to Books), în "România literară“" (Literary Romania), year XLIX, no. 30-31, 14 July 2017, p. 19

${ }^{24}$ The postcard nr. 21 from the exhibits of the Cultural Society "Ştefan Petică", The Museum of History, Galați, Subsidiary Ivești.

22 Aprilie 1896

D-lui Șt. Petică 
Iosif Hussar was Samitca's editor for the Collection of translations, the person who approved and revised the works to be published. Even if Petică knew English, as his closest friends and the high school curricula bear witness, most probably the translation was accomplished through the French version of the book, namely Baudelaire's ${ }^{25}$. It is known that Petică had an interest for Baudelaire's entire activity. Moreover, we have reasons to believe that, had it not been for the interest of Charles Baudelaire, Stéphane Mallarmé and Paul Valery - writers in search of a tutelar spirit - Poe would probably have been an obscure author, since his work was not too appreciated by his American contemporary writers or critics. They held against him the grotesque themes, the deviant behavior of the characters, the lugubrious insides of the described house and the lack of aesthetic value of the works. The popularity in France, then in Europe and in Romania (due to the fact that French was for the Romanian intellectuals some kind of lingua franca at that time) of Edgar Poe's stories was due presumably to Baudelaire's translating talent. The translation of Poe's work by Baudelaire has a great importance in the field of translation studies and particularly in literary translation not only in France, but also in Europe. Baudelaire's translations of Poe have enjoyed an uncommon longevity, since the first one was published in 1839.

\section{Bulev. Cuza, 69, Brăila}

Am primit carta Dv. Poștală din 18/30 p.t. precum și manuscrisul Dv., pe care l'am trimis $d$ lui Hussar la München, ca să se pronunțe asupră’i. Imediat ce vom primi răspunsul D-sale, vi lu vom comunica.

Cu tòtă stima,

R. si I. Samitca

${ }^{25}$ Edgar Allan Poe, La Chute de la maison Usher, Traduction par Charles Baudelaire. Nouvelles Histoires extraordinaires, A. Quantin, 1884, pp. 85-108. Here is a fragment:

Son cour est un luth suspendu;

Sitôt qu'on le touche il résonne.

De Béranger

Pendant toute la journée d'automne, journée fuligineuse, sombre et muette, où les nuages pesaient lourd et bas dans le ciel, j'avais traversé seul et à cheval une étendue de pays singulièrement lugubre, et enfin, comme les ombres du soir approchaient, je me trouvai en vue de la mélancolique Maison Usher. Je ne sais comment cela se fit, - mais, au premier coup d'œil que je jetai sur le bâtiment, un sentiment d'insupportable tristesse pénétra mon âme. Je dis insupportable, car cette tristesse n'était nullement tempérée par une parcelle de ce sentiment dont l'essence poétique fait presque une volupté, et dont l'âme est généralement saisie en face des images naturelles les plus sombres de la désolation et de la terreur. Je regardais le tableau placé devant moi, et, rien qu'à voir la maison et la perspective caractéristique de ce domaine, - les murs qui avaient froid, — les fenêtres semblables à des yeux distraits, - quelques bouquets de joncs vigoureux, — quelques troncs d'arbres blancs et dépéris, - j'éprouvais cet entier affaissement d'âme, qui, parmi les sensations terrestres, ne peut se mieux comparer qu'à l'arrière-rêverie du mangeur d'opium, - à son navrant retour à la vie journalière, - à l'horrible et lente retraite du voile. C'était une glace au cour, un abattement, un malaise, - une irrémédiable tristesse de pensée qu'aucun aiguillon de l'imagination ne pouvait raviver ni pousser au grand. 
We don't know whose proposition was the translation of Poe's stories into Romanian - and the approaching of this literary genre - if the editor or the translator's, anyway, the decision to choose Poe's works for the abovementioned collection of the Publishing House from Craiova was bold, challenging, and maybe a surprise for the Romanian reader at the end of the Nineteenth century.

The two volumes of translations into Romanian include only a few titles from the American writer's stories: The Gold-Bug / Cărăbușul de aur, The Pit and the Pendulum / Puțul și pendula, / The Murders in Rue Morgue / Indoitul asasinat din strada Morgue, / The Purloined Letter / Scrisoarea furată, The Fall of the House Usher / Ruina casei Usher, The Black Cat / Pisica neagră, The Oval Portrait / Portretul oval, The Facts in the Case of M. Valdemar / Adevărul asupra cazului d-lui Valdemar, Hop - Frog / Hop-Frog, The Raven / Corbul.

It is known that due to his precious and complex vocabulary, Poe's texts are very difficult to translate into another language, being a true challenge for the translator. Since Poe dismissed the notion of artistic intuition and argued that writing is methodical and analytical, not spontaneous, the translations from his work should have followed the same principles. We will briefly analyze a fragment, which is the first paragraph translated from Poe's Fall of the House of Usher.

„Son cœur est un luth suspendu;

Sitôt qu'on le touche il résonne.

De Béranger

During the whole of a dull, dark, and soundless day in the autumn of the year, when the clouds hung oppressively low in the heavens, I had been passing alone, on horseback, through a singularly dreary tract of country, and at length found myself, as the shades of the evening drew on, within view of the melancholy House of Usher. I know not how it was - but, with the first glimpse of the building, a sense of insufferable gloom pervaded my spirit. I say insufferable; for the feeling was unrelieved by any of that half-pleasurable, because poetic, sentiment with which the mind usually receives even the sternest natural images of the desolate or terrible. I looked upon the scene before me - upon the mere house, and the simple landscape features of the domain - upon the bleak walls - upon the vacant eye-like windows - upon a few rank sedges - and upon a few white trunks of decayed trees - with an utter depression of soul which I can compare to no earthly sensation more properly than to the after-dream of the reveller upon opium-the bitter lapse into every-day life - the hideous dropping off of the veil. There was an iciness, 
a sinking, a sickening of the heart - an unredeemed dreariness of thought which no goading of the imagination could torture into aught of the sublime ${ }^{26}$.

The translation of the title is accurate, since the Romanian noun "ruina" includes the sense of the fact of being defeated or losing your power, which expresses and describes the atmosphere of decadence of the Usher family. However, from the very beginning we can notice that in Ștefan Petică's version, De Béranger's motto (Son cour est un luth suspendu; Sitôt qu'on le touche il résonne.) is missing.

Even if, in general, Ștefan Petică's transposition has almost the same musicality and reveals the talent and sensibility of a person who is a writer himself, there still are, at least at a lexical level, some differences. Within the passage dull, dark, and soundless day - translated into Romanian as zi $\hat{i n t u n e c a t a ̆ ~ s ̧ i ~ p o s o m o r i ̂ t a ̆ ~-~ t h e ~ t r a n s p o s i t i o n ~ o f ~ o n e ~ o f ~ t h e ~ a d j e c t i v e s, ~}$ respectively soundless is missing. The same happens with the fragment "there was an iciness, a sinking, a sickening of the heart", where the term sinking does not have a correspondent into Romanian: "simţeam inema gheaţă, o lîngezeală nedescrisă”.

The term gloom - which according to the Cambridge Dictionary means: "1. without hope 2. feelings of great unhappiness and loss of hope 3. sadness and regret" (Cambridge Dictionary) - is translated as melancolie (melancholy), losing something from the concept and from the strength of the feeling that the author would have preferred to render. The syntagm as the shades of the evening drew on is also simplified through pe-nserate abia, which loses the idea of shade, but also the idea that the night is installing gradually.

The same happens with an entire expression that in the source language is the after-dream of the reveller upon opium - the bitter lapse into every-day life - the hideous dropping off of the veil - which is transposed into the target

26 Edgar Allan Poe, Ruina Casei Usher, în $<<$ Scrisoarea furată şi alte povestiri extraordinare >>, traducere de St. P., Biblioteca de Popularizare - Literatură, Ştiinţă, Artă, nr. 30, Craiova: Institutul de Editură „Ralian şi Ignat Samitca”, 1897, pp. 31-46.

„, Călărisem singur o zi întreagă de toamnă, zi întunecată şi posomorîtă, cu nouri ce se lăsau greoi jos pe cer, prin nişte locuri foarte triste şi pe-nserate abia am ajuns în faţa melancolicei case Usher. Nu ştiu cum se făcu, că de la prima aruncătură de ochi spre clădire, mă coprinse un adînc şi nesuferit sentiment de melancolie. Zic nesuferit, căci această tristeţă nu era de fel liniştită prin sentimentul poetic ce sufletul nostru simte în faţa celor mai posomorîte imagini de tristeţă sau groază. Priveam tabloul ce se afla-naintea mea, casa şi prespectiva ce mi se înfătişa, zidurile reci, ferestrele asemenea unor ochi distruşi, cîteva tufişuri de trestie, cîteva trunchiuri de copaci albi şi goi - toate acestea mă făceau să simt o sfirş̧eală care, printre senzațiile pămînteşti, nu se poate mai bine compara decît cu enervata reîntoarcere la vieaţă a mîncătorului de opium. Simţeam inema gheaţă, o lîngezeală nedescrisă, eram abătut - mă coprinsese o tristețe de gîndire fără leac, şi nimic pe lume n-ar fi putut s-o facă mai mare." 
language with enervata reîntoarcere la vieață a mîncătorului de opium. The after-dream is not exactly the state, the condition of coming back to life (reîntoarcere la vieaţă).

It is certain that the value of the translations has a mere didactic and cultural value rather than a literary one for the young generation of the crossroads of centuries, since it was one of the first translation of Poe's work into Romanian. Even if the volumes do not include the entire literary creation of Poe, and they seem to be at some extent some interpretations of the American writer's texts than a very accurate translation (the translation of another translation will never be an accurate text), drawing the attention of the Romanian lecturer on such an interesting, original and unique writer - at that time, the intention itself of translating Edgar Allan Poe's work was an important act of aligning the Romanian reader's conscience to the valuable universal literature.

The names that he used in signing the articles, poems and manuscripts were: Stephan Petică, Ştefan, St. Petică, St. P., S. P., P. Ştefan, Erics, Trubadur, Sentino, Narcis, Senez, P. Stiopca, Step., Stepen, Caton, FantaCella, M. Pall, Sapho, S., but as a translator, he used only St. P.

Other translations of Ștefan Petică that can be consulted at the Manuscripts Department of the Romanian Academy Library, from: Walt Whitman, Bodenstedt, Turgheniev, Heine, Th. Moore, but also in literary publications (Walt Whitman, In noaptea clară, in "Ateneul Cultural", I, no. 3, 1925.

\section{Conclusion}

Unfortunately, being sick of tuberculosis, he returned to his native village, in Bucești, to spend the last period of his life, where he passed away on October 17, 1904, only 27 years of age. The other translations that could have been finished and published remained only as drafts in his manuscripts.

\section{References:}

1. Bacovia, George: Ştefan Petică, in $<<$ Ateneul cultural $>>$, I, No 1, martie 1925: Bacău. 1925.

2. Blandiana, Ana: Un lujer străveziu, in $<<$ România literară $>>$, XVII, nr. 48, 29 nov. 1984: București, 1984.

3. Boldea, Iulian: Un simbolist aproape uitat: Ştefan Petică. București: EuroPress Group, 2012.

4. Bote, Lidia: Antologia poeziei simboliste româneşti, Editura pentru Literatură, București, 1968.

5. Călina Presură, Nicoleta: Ștefan Petică - 140. Restituiri. Craiova: Universitaria, 2017. 
6. Călinescu, Matei Ştefan Petică sau poezia muzicii, in vol. Aspecte literare. Bucureşti: Editura pentru Literatură, 1965

7. Călinescu, George: Istoria literaturii române de la origini pînă în prezent. Bucureşti: Minerva 1982.

8. Cioculescu, Şerban; Ştefan Petică -100 , in $<<$ România literară $>>, X$, nr. 3/ 20 ian. 1977. București, 1997

9. Densusianu, Ovid: Şt. Petică, Cîntecul toamnei, Serenade demonice, in $<<$ Viaţa nouă $>>$, V, nr. 16, 1 octombrie 1909.

10. Dimoftache Zeletin, Constantin: Ștefan Petică. 75 de ani de la moarte, in $<<$ România literară $>>$, XII, nr. 40, oct. 1979. București, 1979.

11. Drăgan, Gabriel: Istoria literaturii române (de la origini până în zilele noastre), ediţia a IV-a. Bucureşti: Cugetarea, 1946.

12. Dumitrescu-Buşulenga, Zoe: Ştefan Petică şi prerafaelismul englez, in $<<$ Limbă şi literatură $>>$, X. Bucureşti, 1965.

13. Karnabatt, D.: Boema de altădată, Ştefan Petică. Bucureşti: Vremea, 1944.

14. Manolescu, Nicolae: Istoria critică a literaturii române: 5 secole de literatură. Piteşti: Paralela 45, 2008.

15. Micu, Dumitru: Ştefan Petică, pionierul, in $\langle<$ Tribuna $\rangle>$, XIV, nr. 31 (705)/30 iul 1970. Cluj, 1970

16. Molcuţ, Eufrosina, Ştefan Petică, Scrieri, I-II, Ediţie îngrijită, studiu introductiv, note şi variante de Eufrosina Molcuţ, Seria „Scriitori români”, Editura Minerva, Bucureşti, 1974.

17. Perpessicius, Ştefan Petică: Cavalerul negru, in Opere, II. Bucureşti: Editura pentru Literatură, 1967.

18. Petică, Ştefan: Opere, ediţie îngrijită de N. Davidescu. Bucureşti: Fundaţia pentru Literatură şi Artă „Regele Carol II”, 1938.

19. Petică, Ştefan: Scrieri. I-II, Ediţie îngrijită, studiu introductiv, note şi variante de Eufrosina Molcuţ. Bucureşti: Minerva, 1974.

20. Petică, Ştefan: Opere. Bucureşti: Editura Muzeului Literaturii Române, 2017.

21. Piru, Alexandru: Istoria literaturii române de la început până azi. Bucureşti: Univers, 1981.

22. Poe, Edgar Allan: Nuvele extraordinare, traducere de St. P., colecția Biblioteca de Popularizare - Literatură, Ştiinţă, Artă, nr. 19. Craiova: Institutul de Editură $<<$ Ralian şi Ignat Samitca $>>, 1896$.

23. Poe, Edgar Allan: traducere de St. P., Scrisoarea furată şi alte povestiri extraordinare, Biblioteca de Popularizare - Literatură, Ştiinţă, Artă, nr. 30, Craiova: Institutul de Editură „Ralian şi Ignat Samitca”, 1897.

24. Simion, Eugen: Scriitori români de azi, vol. 1-4. Bucureşti: Cartea Românească, 1978. 
25. Tomescu, Dumitru: Contribuţiuni la istoricul tipografiei oltene „Samitca”, 1835-1922. Craiova: Scrisul Românesc, s.a.

26. Vianu, Tudor: Arta prozatorilor români. Bucureşti: Ed. Contemporană, 1941.

27. Zamfir, Mihai: Ştefan Petică, unicul, in $<<$ România literară $>>$, XLIX, nr. 30-31, 14 iulie 201. București, 2017. 